\title{
Chemical Profiling of Acalypha indica Obtained from Supercritical Carbon Dioxide Extraction and Soxhlet Extraction Methods
}

\section{SURANGKANA CHAICHOOWONG ${ }^{1}$, JAN BERND BOL ${ }^{2}$, PORNPRAPA BOL ${ }^{3}$, THOMAS GAMSE ${ }^{2}$ and MALINEE SRIARIYANUN ${ }^{1 *}$}

${ }^{1} T$ The Sirindhorn International Thai-German Graduate School of Engineering (TGGS),

KMUTNB, Bangkok, 10800 Thailand.

${ }^{2}$ Graz University of Technology, Institute of Chemical Engineering and

Environmental Technology, NAWI Graz, Graz, 8010 Austria.

${ }^{3}$ Rajamangala University of Technology Thanyaburi, Thailand, Pathum Thani, 12110 Thailand.

${ }^{*}$ Corresponding author E-mail: macintous@gmail.com

http://dx.doi.org/10.13005/ojc/330107

(Received: November 08, 2016; Accepted: December 12, 2016)

\begin{abstract}
Acalypha indica is a weed that grows in South-East Asia. It contains several valuable compounds that can be used for curing various diseases such as rheumatism, skin infection and blood dysentery. Here, the extraction of $A$. indica using Soxhlet extraction with two different solvents and supercritical $\mathrm{CO}_{2}$ extraction (SCE) with two different temperatures $\left(40\right.$ and $\left.60^{\circ} \mathrm{C}\right)$ was performed. In Soxhlet extraction, ethanol solvent provided the highest extraction yield of $34.36 \%$. For SCE, the increased temperature has positive effect and the yield of the SCE process (the highest extraction yield was $0.89 \%$ ) was lower than that of the Soxhlet extraction using hexane $(8.3 \%)$. Then, the extracted compound profilings were analysed by gas chromatography-mass spectrometer (GC-MS). The extraction selectivity of active compounds obtained from each extraction methods was observed. These results suggested the trade-off between yield and selectivity of extraction to obtain bioactive compounds from $A$. indica.
\end{abstract}

Keywords: Acalypha indica, Chemical profiling, Supercritical $\mathrm{CO}_{2}$ extraction, Soxhlet extraction.

\section{INTRODUCTION}

Acalypha indica is one of weed plants that contains important phytochemicals for human health applications. It can be found commonly in India, Pakistan, Sri Lanka and Thailand. The extracts of this plant from leaves, roots and stem parts are used for medicinal purposes to treat various diseases such as the skin problems, eye infections, respiratory problems, rheumatism and to decrease blood sugar level ${ }^{1-2}$. Moreover, $A$. indica extract shows antibacterial activity and it has a cat attractant compound that has an effect on cat behavior ${ }^{3}$. Different extraction techniques are used for obtaining 
active components from $A$. indica ${ }^{4-6}$. Generally, Soxhlet extraction has a high efficiency, but the thermal stress might degrade target components. Solid-liquid extraction is usually performed at lower temperature, but shows a lower extraction efficiency. Both methods can be performed by using different solvents as a selective extraction ${ }^{\text {? }}$.

In some cases, supercritical fluid extraction (SFE) gains interest for this application. At specific condition of pressure and temperature, the supercritical fluid has behavior between liquid and gas. Supercritical fluids are similar to liquid that has high density as well as they are similar to gas that has elevated diffusivity and low viscosity. $\mathrm{CO}_{2}$ is commonly used in SFE because it has several unique characteristics and physical and chemical properties including being non-toxic, non-flammable, inexpensive, as well as a low critical pressure and temperature when compared with other solvents ${ }^{8-9}$. There are several parameters that have effects on performance of the SFE method such as temperature, pressure, extraction time and type of solvent. SFE technique could be coupled with the solvent such as ethanol, $\mathrm{CO}_{2}$, propane, butane, or ethylene and it has been received interest in many researches and also in chemical, food, pharmaceutical and biochemical industries ${ }^{10}$. Although several extraction methods can be used to obtain natural compounds from plant, the SFE can avoid some disadvantages observed in other methods.

In this study, we aimed to study chemical profiling of $A$. indica obtained from different extraction methods to identify chemical composition and yield depending on the characteristic of each extraction methods. The abundance of specific active compounds was analyzed to select the highest efficient extraction method to further apply in larger scale of production.

\section{MATERIALS AND METHODS}

\section{Plant material preparation}

The whole plants of $A$. indica were collected from Central part of Thailand, near Bangkok. The samples were collected in October 2015, when the ambient temperature was about $32-35^{\circ} \mathrm{C}$. They were dried under sunlight for 3 days. The moisture content was $6.88 \%$. It was determined gravimetrically by drying $100 \mathrm{~g}$ of sample in a hotair oven at $105^{\circ} \mathrm{C}$ for $5 \mathrm{~h}$ and measuring the loss of sample weight. Then, samples were crushed with basic analysis mill (IKA A11, Germany) and particle sizes were screened by sieving machine (Retsch AS 200, Germany). A particle size of 300-400 $\mu \mathrm{m}$ was selected for all extraction experiments.

\section{Soxhlet extraction}

Fourteen grams of $A$. indica powders were subjected to Soxhlet extraction by placing in thimble and then transferred to a Soxhlet extractor. The bottom of extraction flask was filled with 250 $\mathrm{ml}$ of solvents (ethanol or hexane). The solvent was heated under reflux for $2 \mathrm{~h}$. After an extraction run was completed, the solvent was removed at $80{ }^{\circ} \mathrm{C}$ with a rotary evaporator. The extracted samples were collected for analyzing the extracted components. Finally, the extraction yield was calculated as shown in equation 1.

$$
\text { Extraction yieldi } \%=\frac{\text { mass of tatal exfracted compound }}{\text { mass of raw material }} \times 100
$$

\section{Supercritical fluid extraction}

Supercritical extraction was carried out in a Speed SFE unit (Applied Separation, Allentown, PA) (Fig. 1). Sixty-seven g of dried A. indica powder was packed in $300 \mathrm{ml}$ extraction vessel, which was covered by insulated furnace (sample volume occupied $83 \%$ space volume of vessel). Initially, the vessel was filled with supercritical $\mathrm{CO}_{2}$ pumped from a storage cylinder. The plant materials were extracted by flowing of supercritical $\mathrm{CO}_{2}$ with up-flow direction. The volumetric $\mathrm{CO}_{2}$ flow rate was measured by a gas flow meter with $28.25 \mathrm{~g} / \mathrm{min}$ of average $\mathrm{CO}_{2}$ mass flow. The experiments were accomplished at a constant extraction pressure of 300 bar and temperatures of 40 and $60^{\circ} \mathrm{C}$ for an extraction time of $90 \mathrm{~min}$. Then the vessel was depressurized to atmospheric pressure. During the experiment the extracted substances were collected within the vial for further analysis by GC-MS.

\section{GC-MS analysis}

Components of plant extracts were analyzed by GC-MS. The analysis was performed using a Shimadzu GCMS-QP2010S system equipped with a HP-5MS column $(30 \mathrm{~m} \times 250 \mu \mathrm{m} ; 0.25 \mu \mathrm{m}$ film 
thickness), using Helium as carrier gas. The oven temperature was set at $40^{\circ} \mathrm{C}$ hold for $1 \mathrm{~min}, 280^{\circ} \mathrm{C}$ at $5^{\circ} \mathrm{C} / \mathrm{min}$ and $280^{\circ} \mathrm{C}$ hold for $5 \mathrm{~min}$. The sample was injected to column at split ratio of $30: 1$. The MS scanning time was set at 1 sec period and mass range of 35-700 amu. The MS spectra were aligned with NIST database (year 2011). The amount percentages of compounds were calculated by area normalization method.

\section{RESULT AND DISCUSSION}

In Soxhlet extraction, ethanol and hexane were used as solvents in this study. The experimental results showed that the extraction yield obtained by using two solvents were quite different. Clearly, ethanol extraction showed four times higher yield than hexane over the same extraction time. The extraction yield extracted by ethanol at $2 \mathrm{~h}$ was $34.36 \%$ which was nearly four times from hexane at $8.30 \%$ (Table 1). From this extraction experiment, the solvent types and properties have a strong influence on extraction yield. Ethanol solvent achieved the higher extraction yield because ethanol, owing to its polar nature, can extract not only the polar compounds that are not dissolvable in hexane, but also non-polar components.
In SFE, the constant pressure of 300 bar and temperatures of $40^{\circ} \mathrm{C}$ and $60^{\circ} \mathrm{C}$ were selected. When the temperature was increased from $40^{\circ} \mathrm{C}$ to $60^{\circ} \mathrm{C}$, the extraction yield increased from $0.6586 \%$ to $0.8924 \%$ indicating that higher temperature has a positive effect on the extraction yield. Therefore, the increase in the extractability of compound within this temperature range was caused by enhanced solubility of extractable substances in supercritical $\mathrm{CO}_{2}$. However, increasing of operational temperature could have negative effect on the extraction yield, depending on extraction pressure. For example, SFE was previously applied to extract active compounds of Eucalyptus leaves. It was demonstrated that increasing temperature resulted in a decrease of extraction yield at low pressure. Oppositely, at

Table 1: Extraction yield of $\boldsymbol{A}$. indica obtained from Soxhlet and SFE extraction

\begin{tabular}{lc}
\hline Extraction methods & Extraction yield (\%) \\
\hline Soxhlet extraction & \\
Ethanol & 34.3571 \\
Hexane & 8.3043 \\
Supercritical $\mathrm{CO}_{2}$ extraction & \\
$40^{\circ} \mathrm{C}, 300$ bars & 0.6586 \\
$60^{\circ} \mathrm{C}, 300$ bars & 0.8924 \\
\hline
\end{tabular}

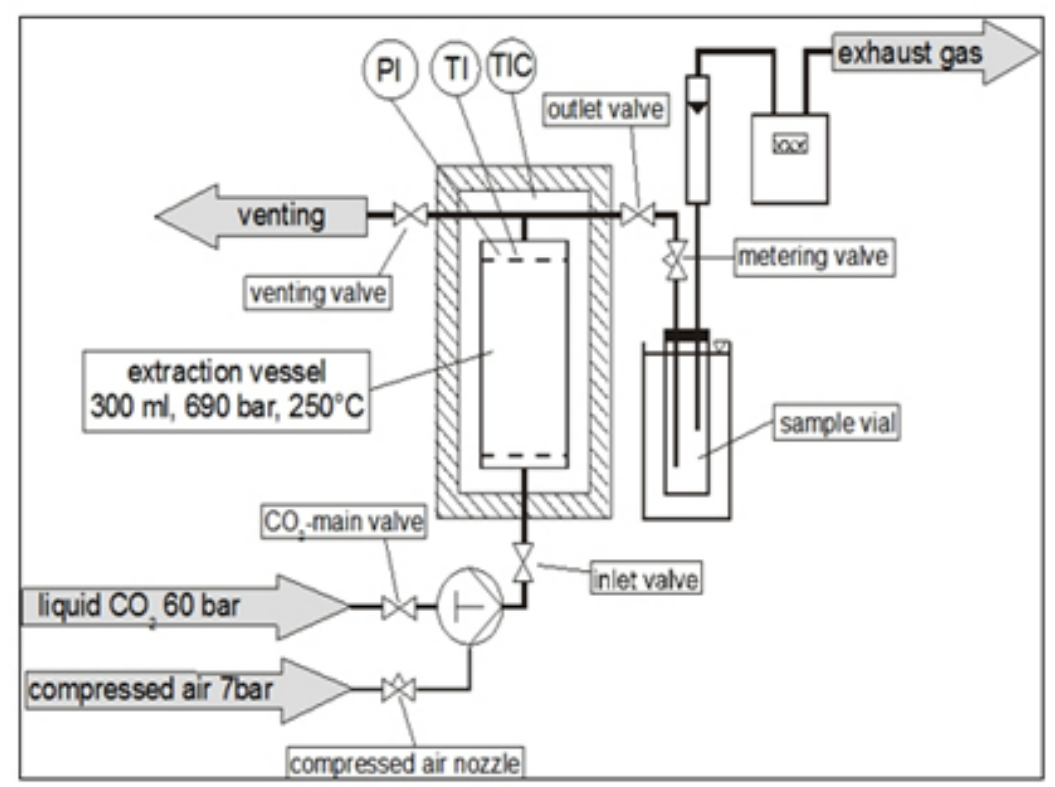

Fig. 1: Diagram of supercritical $\mathrm{CO}_{2}$ extraction system 
high pressure, the extracted yield increased when operational temperature increased. This observation is in agreement the general know-how that an increase in temperature is only positive at higher pressure level. Otherwise at higher temperatures the decrease in SCF density is the dominating effect, resulting in lower extraction yields ${ }^{9}$.

In order to identify the chemical composition of extractants obtained from Soxhlet and SFE, the samples were analyzed by using GC-MS. Based on the chemical profiles, the ethanol-Soxhlet extractants had the most numbers of chemicals (36 compounds). While, the hexane-Soxhlet extractants, SFE at $40^{\circ} \mathrm{C}$ and SFE at $60^{\circ} \mathrm{C}$ had 19,23 and 27 compounds. The ethanol extracts contained compounds that were not detected in hexane-Soxhlet. In SFE extraction, the numbers of compounds extracted at $60^{\circ} \mathrm{C}$ were higher than those obtained by SFE at $40^{\circ} \mathrm{C}$, although most chemical members were similar, which $73.91 \%$ of members obtained from SFE at $40^{\circ} \mathrm{C}$ were belonged to SFE at $60^{\circ} \mathrm{C}$.

To investigate the chemical profiling of each extractant, the relative abundance of each chemical was calculated and ten compounds that were the most abundant chemicals of each extractant were listed as shown in Fig 2. To find the biological properties of these top ten abundant chemicals in extractants, only the chemicals whose properties and activities have been studied previously were described here (Table 2). The ethanol-Soxhlet extractant contained 9-Tricosene (4.63\%), phytol (12.49\%) and MOME inositol (27.22\%), while the hexane-Soxhlet extractant contained dihydroactinidiolide (1.31\%), Ioliolide (1.92\%) and phytol (37.16\%). For SFE, the extractant at $40{ }^{\circ} \mathrm{C}$ was composed of docosanol $(3.68 \%)$ and phytol (16.15\%), while extractant at $60{ }^{\circ} \mathrm{C}$ was consisted of 1 -eicosanol $(6.64 \%)$, phytol (26.60\%) and 1-triacontanol (32.52\%). Although
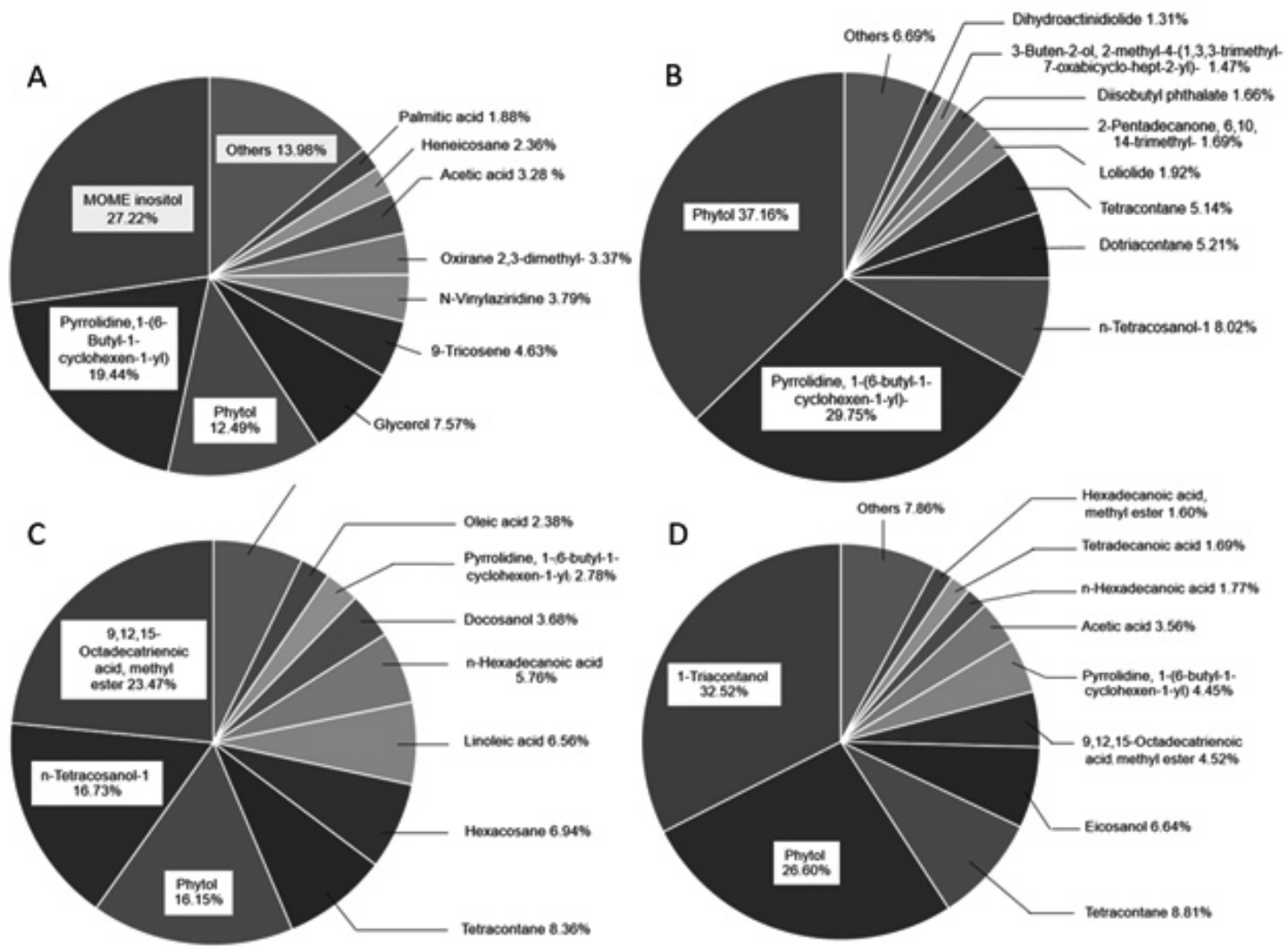

Fig. 2: Chemical profilings of top 10 most abundant compounds of $A$. indica obtained from (A) Soxhlet with ethanol, (B) Soxhlet with hexane, (C) SFE extraction at $40^{\circ} \mathrm{C}$ and (D) SFE extraction at $60^{\circ} \mathrm{C}$ 
there were many active compounds obtained from $A$. indica extractants in this study, these top ten abundant compounds could be considered to be potential candidates for production in large scale based on its quantitative availability.

Based on lists of active compounds obtained from $A$. indica (Table 2), the extraction selectivity of each method was demonstrated. Theoretically, hexane and $\mathrm{CO}_{2}$ SFE are suggested to extract non-polar compounds based on the solvent polarities. Therefore, the similar patterns of chemical profiles from these two methods should be expected. However, there were only two active compounds, phytol and dihydroactinidiolide, observed in both hexane and SFE fractions with much difference of percent abundance. For example, there was $1.31 \%$ of dihydroactinidiolide in hexane fraction, but there was only $0.27 \%$ and $0.48 \%$ in SFE at $40^{\circ} \mathrm{C}$ and $60^{\circ} \mathrm{C}$, respectively. Clearly, active compounds, including docosanol, 1-eicosanol, 1-triacontanol, Tricosane, 9,12-Octadecadienoic acid $(Z, Z)$, methyl ester, Hexanedioic acid and bis(2ethylhexyl) ester, were extracted only by using SFE

Table 2: Bioactive compound of $A$. indica and its biological properties

\begin{tabular}{|c|c|c|}
\hline Compounds & Types of extractants* & Possible biological properties \\
\hline 9-Tricosene & ESE & Insect pheromone; Pesticides ${ }^{11-12}$ \\
\hline Phytol & ESE, HSE, SFE1, SFE2 & $\begin{array}{l}\text { Antimicrobial, cytotoxic, antitumorous, } \\
\text { antimutagenic, anti-teratogenic, antibiotic- } \\
\text { chemotherapeutic, antidiabetic }^{13} \text {. }\end{array}$ \\
\hline MOME inositol & ESE & $\begin{array}{l}\text { Anti-alopecic, anti-cirrhotic, anti-neuropathic, } \\
\text { cholesterolytic, lipotropic and a sweetener }{ }^{14} \text {. }\end{array}$ \\
\hline Dihydroactinidiolide & ESE, HSE,SFE1, SFE2 & $\begin{array}{l}\text { Pheromone for insects, cat attractant; } \\
\text { Photoacclimation in plants }{ }^{15-16} \text {. }\end{array}$ \\
\hline Loliolide & ESE, HSE & $\begin{array}{l}\text { Inhibitor of hepatitis C virus entry; Inhibitor of } \\
\text { cellular senescence in human dermal } \\
\text { fibroblasts } \\
\text { 17-18. }\end{array}$ \\
\hline Docosanol & SFE1, SFE2 & Antivital agent of herpes simplex virus ${ }^{19}$. \\
\hline 1-Eicosanol & SFE2 & $\begin{array}{l}\text { Antitumor activity in vitro and in vivo in mice } \\
\text { model; antibacterial and antifungal activity }{ }^{20-21} \text {. }\end{array}$ \\
\hline 1-Triacontanol & SFE2 & Promotion of plant growth and flowering ${ }^{22-23}$. \\
\hline $\begin{array}{l}\text { 3,7,11,15-Tetramethyl } \\
\text {-2-hexadecen-1-ol }\end{array}$ & ESE & Drug resistance reversal agents ${ }^{24}$ \\
\hline Octacosanol & ESE & $\begin{array}{l}\text { Controlling of blood metabolism, growth and } \\
\text { laying performance in poutry; Proliferation and } \\
\text { migration of human umbilical vein endothelial } \\
\text { cells }^{25-26} \text {. }\end{array}$ \\
\hline $\begin{array}{l}\text { 5,10-Diethoxy-2,3,7, } \\
\text { 8-tetrahydro-1H, } \\
\text { 6H-dipyrrolo } \\
{\left[1,2-\mathrm{a} ; 1^{\prime}, 2^{\prime} \text {-d]pyrazine }\right.}\end{array}$ & ESE & Antifungal activity ${ }^{27}$ \\
\hline Tricosane & SFE1, SFE2 & Insect pheromone; Pesticides ${ }^{28}$. \\
\hline $\begin{array}{l}\text { 9,12-Octadecadienoic } \\
\text { acid }(Z, Z) \text {, methyl ester }\end{array}$ & SFE1, SFE2 & Anticancer ${ }^{29}$ \\
\hline $\begin{array}{l}\text { Hexanedioic acid, } \\
\text { bis(2-ethylhexyl) ester }\end{array}$ & SFE1 & Antibacterial activity ${ }^{30-31}$. \\
\hline
\end{tabular}

${ }^{\star} \mathrm{ESE}=$ ethanol-Soxhlet extraction, HSE $=$ hexane-Soxhlet extraction, SFE1 $=$ SFE at $40{ }^{\circ} \mathrm{C}$ and SFE2 = SFE at $60^{\circ} \mathrm{C}$ 
Table 3: Percent abundance of selected active compounds found in extractants obtained from Soxhlet extraction and SFE

\begin{tabular}{lcccc}
\hline Compounds & & \multicolumn{2}{c}{ Extraction methods } & \\
& Ethanol-Soxhlet & Hexane-Soxhlet & SFE at $\mathbf{4 0} 0^{\circ} \mathbf{C}$ & SFE at $60^{\circ} \mathbf{C}$ \\
\hline Phytol & 12.4 & 37.16 & 16.15 & 26.6 \\
Dihydroactinidiolide & 0.32 & 1.31 & 0.27 & 0.48 \\
Loliolide & 1.10 & 1.92 & n.d. ${ }^{*}$ & n.d. \\
\hline
\end{tabular}

${ }^{*}$ n.d. not detected.

methods. On the other hand, 9-Tricosene, MOME inositol, 3,7,11,15-Tetramethyl-2-hexadecen-1-ol, Octacosanol and 5,10-Diethoxy-2,3,7,8-tetrahydro$1 \mathrm{H}, 6 \mathrm{H}$-dipyrrolo[1,2-a;1',2'-d]pyrazine, were extracted only by using ethanol-Soxhlet method.

Difference of chemical profiles was not only found in the types of members but also abundance of chemicals. The results here showed that three active compounds, including phytol, dihydroactinidiolide and loliolide were differentially extracted from $A$. indica in abundance although they were found in different extractants (Table 3 ). Dihydroactinidiolide, a cat attractant, is similar to nepetalactone, which found in catnip plants ${ }^{15}$. In this study, dihydroactinidiolide was obtained with the highest abundance when using hexane-Soxhlet extraction and this is about 5 times more compared to SFE at $40{ }^{\circ} \mathrm{C}$. It is known that hexane is a nonpolar solvent and dihydroactinidiolide as non-polar compound thereof more easily extracted by hexane. On the other hand, 1-eicosonal and 1-triacontanol were abundant in the extractant obtained from SFE at $60{ }^{\circ} \mathrm{C}$. with $6.64 \%$ and $32.52 \%$. These two active compounds have interesting biological activities as tumor inhibitor and plant hormone, respectively 20 ${ }^{23}$ (Table 2). Using SFE method, very high extraction selectivity could be achieved, but with lower product yield (Table 1). Therefore, it is important to consider the trade-off between selectivity and yield of targeted

\section{REFERENCES}

1. Seebaluck R, Gurib-Fakim A, Mahomoodally F. Medicinal plants from the genus Acalypha active compound to fit with downstream fractionation for further applications.

\section{CONCLUSION}

In this study, two different extraction methods of $A$. indica were performed for isolation of valuable components. The extraction yields and chemical composition obtained by Soxhlet and SFE were also compared. The extraction selectivity of each method revealed differential chemical profiling of active compounds that have been shown previously to have importance and potential in medicinal and biological uses, such as antimicrobial, plant and animal pheromones, anti-tumor, anti-cellular senescence. The results of chemical profiling from this study could be used to compare with previous studies about extraction of $A$. indica to better understand the chemical mechanism of this plant to be used for further applications in medicinal and biological purposes.

\section{ACKNOWLEDGEMENT}

The authors would like to extend gratitude to Ing. Herta Luttenberger, Institute of Chemical Engineering and Environmental Technology, Graz University of Technology for her comments and suggestion for GC-MS analysis. Also, authors would like to thank TGGS and KMUTNB for financial support of this work and graduate study scholarship to Chaichoowong S.

(Euphorbiaceae) - A review of their ethnopharmacology and photochemistry. $J$ Ethnopharmacol. 2015; 54: 137-157. 
2. Nahrstedt A, Hungeling $M$, Petereit F. Flavonoids from Acalypha indica. Fitoterapia. 2006; 77(6): 484-6.

3. Govindarajan M, Jebanesan A, Reetha D, Amsath R, Pushpanathan T, Samidurai K. Antibacterial activity of Acalypha indica $L$. Antibacterial activity of Aca Medical and Pharmacological. Sciences. 2008; 12: 299302.

4. Mouli KC, Vijaya T, Dattatreya Rao S. Effectiveness of flavonoid-rich leaf extract of Acalypha indica in reversing experimental myocardial ischemia: biochemical and histopathological evidence. Zhong Xi Yi Jie He Xue Bao. 2012; 10(7): 784-92.

5. Rahman MA, Bachar SC, Rahmatullah M. Analgesic and antiinflammatory activity of methanolic extract of Acalypha indica Linn. Pak J Pharm Sci. 2010; 23(3): 256-8.

6. Krishnaraj C, Jagan EG, Rajasekar S, Selvakumar P, Kalaichelvan PT, Mohan N. Synthesis of silver nanoparticles using Acalypha indica leaf extracts and its antibacterial activity against water borne pathogens. Colloids Surf B Biointerfaces. 2010; 76(1): 50-6.

7. Mushtaq MY, Choi YH, Verpoorte R, Wilson EG. Extraction for metabolomics: access to the metabolome. Phytochem Anal. 2014; 25(4): 291-306.

8. Capuzzo A, Massimo EM, Occhipinti A. Supercritical fluid extraction of plant flavors and fragrances. Molecules. 2013; 18: 71947238

9. Suwei Z, Dongke Z. Supercritical CO2 extraction of Eucalyptus leaves oil and comparison with Soxhlet extraction and hydro-distillation methods. Sep Puri Technol. 2014; 133: 443-451.

10. King JW. Modern supercritical fluid technology for food applications. Annu Rev Food Sci Technol. 2014; 5: 215-38.

11. Lin CC, Prokop-Prigge KA, Preti G, Potter CJ. Food odors trigger Drosophila males to deposit a pheromone that guides aggregation and female oviposition decisions. Elife. 2015; 4: e08688.

12. Kavran M, Zgomba MF, Ignjatovic-ÆEupina AM, Laziæ SD, Petriæ DV. Choice of optimal biocide combination to control flies (Diptera:
Muscidae). Ann Agric Environ Med. 2015; 22(2): 243-6

13. Islam MT, de Alencar MV, da Conceição Machado K, da Conceição Machado K, de Carvalho Melo-Cavalcante AA, de Sousa DP, de Freitas RM. Phytol in a pharma-medicostance. Chem Biol Interact. 2015; 240: 6073.

14. Kumar NR, Reddy JS, Gopikrishna G, Solomon KA. GC-MS determination of bioactive constituents of Cycas beddomei cones. Int J Pharm Bio Sci. 2012; 3(3): 344-350.

15. Albone ES. Dihydroactinidiolide in the supracaudal scent gland secretion of the red fox. Nature. 1975; 256(5518): 575.

16. Shumbe L, Bott $R$, Havaux $M$. Dihydroactinidiolide, a high light-induced â-carotene derivative that can regulate gene expression and photoacclimation in Arabidopsis. Mol Plant. 2014; 7(7): 1248-51.

17. Chung CY, Liu CH, Burnouf T, Wang GH, Chang SP, Jassey A, Tai CJ, Tai CJ, Huang CJ, Richardson CD, Yen MH, Lin CC, Lin LT. Activity-based and fraction-guided analysis of Phyllanthus urinaria identifies loliolide as a potent inhibitor of hepatitis $C$ virus entry. Antiviral Res. 2016; 130: 58-68.

18. Yang $\mathrm{HH}$, Hwangbo $\mathrm{K}$, Zheng $\mathrm{MS}$, Cho $\mathrm{JH}$, Son JK, Kim HY, Baek SH, Choi HC, Park SY, Kim JR. Inhibitory effects of (-)-loliolide on cellular senescence in human dermal fibroblasts. Arch Pharm Res. 2015; 38(5): 876-84.

19. Leung DT, Sacks SL. Docosanol: a topical antiviral for herpes labialis. Expert Opin Pharmacother. 2004; 5(12): 2567-71.

20. Figueiredo CR, Matsuo AL, Massaoka $\mathrm{MH}$, Girola N, Azevedo RA, Rabaça AN, Farias CF, Pereira FV, Matias NS, Silva LP, Rodrigues EG, Lago JH, Travassos LR, Silva RM. Antitumor activity of Kielmeyera coriacea leaf constituents in experimental melanoma, tested in vitro and in vivo in syngeneic mice. Adv Pharm Bull. 2014; 4(Suppl 1): 429-36.

21. Kavitha A1, Prabhakar P, Vijayalakshmi M, Venkateswarlu Y. Production of bioactive metabolites by Nocardia levis MK-VL_113. Lett Appl Microbiol. 2009; 49(4): 484-90.

22. Khandaker MM, Faruq G, Rahman MM, 
Sofian-Azirun M, Boyce AN. The influence of 1-triacontanol on the growth, flowering, and quality of potted Bougainvillea plants (Bougainvillea glabra var. "Elizabeth Angus") under natural conditions. ScientificWorldJournal. 2013; 2013: 308651.

23. Ramanarayan K, Swamy GS. Triacontanol negatively modulates the jasmonic acidstimulated proteinase inhibitors in tomato (Lycopersicon esculentum). J Plant Physiol. 2004; 161(4): 489-92.

24. Upadhyay HC, Dwivedi GR, Roy S, Sharma A, Darokar MP, Srivastava SK. Phytol derivatives as drug resistance reversal agents. ChemMedChem. 2014; 9(8): 1860-8.

25. Peng K, Long L, Wang Y, Wang S. Effects of octacosanol extracted from rice bran on the laying performance, egg quality and blood metabolites of laying hens. Asian-Australas $J$ Anim Sci. 2016. E-published ahead of print.

26. Liu YW, Zuo PY, Zha XN, Chen XL, Zhang R, He XX, Liu CY. Octacosanol enhances the proliferation and migration of human umbilical vein endothelial cells via activation of the PI3K/Akt and MAPK/Erk pathways. Lipids. 2015; 50(3): 241-51.

27. Li H, Liu L, Zhang S, Cui W, Lv J. Identification of antifungal compounds produced by Lactobacillus casei AST18. Curr Microbiol. 2012; 65(2): 156-61.

28. Silberbush A, Markman S, Lewinsohn E, Bar E, Cohen JE, Blaustein L. Predator-released hydrocarbons repel oviposition by a mosquito. Ecol Lett. 2010; 13(9): 1129-38.

29. Kumar PP, Kumaravel S, Lalitha C. Screening of antioxidant activity, total phenolics and GC-MS study of Vitex negundo. African $J$ Biochem Res. 2010; 4(7): 191-5.

30. Ge S, Peng W, Li D, Mo B, Zhang M, Qin D. Study on antibacterial molecular drugs in Eucalyptus granlla wood extractives by GC-MS. Pak J Pharm Sci. 2015; 28(4 Suppl): 1445-8.

31. Peng W, Ge S, Li D, Mo B, Daochun Q, Ohkoshi M. Report: Molecular basis of antibacterial activities in extracts of Eucommia ulmoides wood. Pak J Pharm Sci. 2014; 27(6 Suppl): 2133-8. 